Studia nad Autorytaryzmem i Totalitaryzmem 43, nr 3

Wrocław 2021

https://doi.org/10.19195/2300-7249.43.3.12

\author{
WOJCIECH ZALEWSKI \\ ORCID: 0000-0001-5539-7162 \\ Uniwersytet Gdański \\ wojciech.zalewski@ug.edu.pl
}

\title{
Społeczna szkodliwość — dziedzictwo komunizmu w polskim prawie karnym?
}

\begin{abstract}
Słowa kluczowe: społeczna szkodliwość, społeczne niebezpieczeństwo, materialna treść przestępstwa, prawo karne, polityki kryminalna, kara.
\end{abstract}

\section{SOCIAL HARMFULNESS: THE HERITAGE OF COMMUNISM IN POLISH CRIMINAL LAW?}

\begin{abstract}
The introduction of social harmfulness (social danger) to Polish criminal law after the Second World War was politically motivated. For many, this circumstance was sufficient to formulate postulates about the necessity to remove this premise of criminal liability. Social harmfulness still remains controversial today. Before, criminal law was seen as a tool. Currently, it is to be an ultima ratio. It is clear that determining the essence of the crime and its nature, introducing into the law "what belongs to literature", was necessary in the legal system of a totalitarian state, imposing its views and morals on society. In a legal system of a democratic state, a state ruled by law, a statutory ideological declaration regarding the essence of a crime seems redundant. However, changing the nomenclature is not enough here - there is a possibility of weakening the guaranteeing criminal law function. The social harmfulness premise contributes to the heterogeneity of jurisprudence, even in cases concerning serious crimes. The author is of the opinion that limiting the number of minor cases from the point of view of the state's right to punish, which paralyzes the judiciary with their sheer number, should take place in a different way than introducing the social harmfulness of an act as a criterion determining the culpability. The currently adopted solution seems irrational and non-functional from the perspective of the legal certainty principle. A more appropriate move seems to be the assessing the advisability of prosecuting an act, i.e. by introducing and implementing the principle of opportunism in criminal proceedings.
\end{abstract}

Keywords: social harmfulness, social danger, material content of the crime, criminal law, criminal policy, punishment. 


\section{Uwagi wprowadzające}

Polskie prawo karne i ogólnie wymiar sprawiedliwości w sprawach karnych korzysta z dziedzictwa przeszłości. Obowiązujący dziś kodeks karny jest w wielu aspektach następcą swojego poprzednika z 1969 roku, zwanego kodeksem Andrejewa. Komisja kodyfikacyjna w 1997 roku próbowała co prawda odejść od przeszłości: eksponowano pozytywną prewencję kryminalną, zrezygnowano z kary śmierci, odwrócono hierarchię kar, dając pierwszeństwo karom wolnościowym, wskazywano na konieczność wzmocnienia roli pokrzywdzonego i funkcji kompensacyjnej w prawie karnym, rozszerzono tak zwany kompleks cywilnoprawny w prawie karnym itp. Już na etapie prac parlamentarnych wprowadzono do kodeksów karnych mediację, główną instytucję nowego paradygmatu w podejściu do problematyki przestępczości - sprawiedliwości naprawczej $^{1}$. W praktyce zmiany te na niewiele się zdały. Wymiar sprawiedliwości szedł utartymi koleinami. Nadal w praktyce orzeczniczej przeważała kara pozbawienia wolności z warunkowym jej zawieszeniem, często stosowano bezwzględną karę pozbawiania wolności, nadal dużo częściej w porównaniu z krajami zachodnimi orzekano karę bezwzględnego pozbawiania wolności, sięganie po instytucje probacyjne było rzadsze, niż oczekiwano, niewiele zmieniła się struktura orzekania pozostałych sankcji ${ }^{2}$. W związku z prowadzoną polityką karną konieczna stała się znaczna nowelizacja kodeksów karnych, której dokonano w 2015 roku $^{3}$. Wiele instytucji pozostawiono jednak bez zmiany ${ }^{4}$, w tym fundament polskiego powojennego prawa karnego w postaci społecznej szkodliwości czynu jako przesłanki odpowiedzialności karnej.

Istotne pytanie, jakie się nasuwa, dotyczy powodów takiego stanu. Z całą pewnością było i jest ich dużo. Niedokończona transformacja ustrojowa ${ }^{5}$, niedostateczne zmiany organizacyjne, niedofinansowanie wymiaru sprawiedliwości, brak pełnej kontradyktoryjności i oportunizmu w ściganiu, określone warunki otoczenia społeczno-gospodarczego, które ograniczają stosowanie kar wolnościowych, między innymi grzywien, punitywne nastawienie społeczeństwa, utarte

${ }^{1}$ Por. więcej o tym W. Zalewski, Sprawiedliwość naprawcza. Początek ewolucji polskiego prawa karnego?, Gdańsk 2006.

2 Por. przede wszystkim opracowania M. Melezini, Punitywność polskiego wymiaru sprawiedliwości w XX wieku, Białystok 2003; eadem, Środki karne jako instrument polityki kryminalnej, Białystok 2013. W zakresie probacji zwłaszcza A. Bałandynowicz, Probacyjna sprawiedliwość karząca, Warszawa 2015; K. Krajewski, Spór o politykę karna w Polsce: problem kary pozbawienia wolności z warunkowym zawieszeniem jej wykonania i alternatyw pozbawienia wolności, „Przegląd Więziennictwa Polskiego" 2007, nr 54, s. 7 n.

3 W dniu 20 lutego 2015 r. Sejm RP uchwalił ustawę o zmianie ustawy - Kodeks karny oraz niektórych innych ustaw, Dz.U. z 20 marca 2015 r. poz. 396.

4 Por. przegląd krytyczny instytucji k.k. w K. Daszkiewicz, Kodeks karny z 1997 roku. Uwagi krytyczne, Gdańsk 2001.

5 Por. więcej np. A. Dudek, Reglamentowana rewolucja, Warszawa 2014. 
schematy polityczno-kryminalne, rutyna $\mathrm{w}$ orzekaniu itp. Jednym z głównych powodów było i jest niezerwanie do końca $\mathrm{z}$ filozofią komunistycznego prawa, w tym zwłaszcza posługiwanie się, fundamentalną dla niego, tak zwaną materialną definicją przestępstwa. Transformacja prawa nie może w pełni się dokonać bez zerwania z tym dziedzictwem. Społeczna szkodliwość jako przesłanka odpowiedzialności nie tylko określa istotę przestępstwa, lecz także narzuca określony styl myślenia o prawie i państwie.

Powodów zajęcia się materialną treścią przestępstwa można więc wymienić wiele. Elementarny łączy się z tezą niniejszego tekstu i związany jest z końcowym postulatem de lege ferenda. Postaram się wykazać, że społeczna szkodliwość (dawniej — niebezpieczeństwo) jest ciągle zagrażającym praworządności dziedzictwem komunistycznym (szerzej totalitarnym). Powstaje pytanie: czy istotnie po tylu latach należy z niej rezygnować? Czy niebezpieczeństwo nie minęło? Czy obawy nie są płonne? W razie odpowiedzi przeczącej pozostaną do analizy niełatwe problemy związane ze stosowaniem tej instytucji, a którym należy się, choćby skrótowo, przyjrzeć. $\mathrm{W}$ razie odpowiedzi pozytywnej powstanie problem: co w zamian?

\section{Geneza wprowadzenia społecznego niebezpieczeństwa do polskiego prawa karnego w okresie powojennym}

Pierwotnie społeczne niebezpieczeństwo trafiło do polskiego prawa karnego pod koniec lat czterdziestych w kształcie, który wydaje się akceptowalny nawet we współczesnych państwach o utrwalonej demokracji. Wprowadzono je w 1949 roku do kodeksu postępowania karnego z 1928 roku, nadając społecznemu niebezpieczeństwu kształt dyrektywy polityczno-kryminalnej, tworzącej podstawę oportunistycznego umorzenia postępowania. Artykuł 49 k.p.k. z 1928 roku stanowił po wskazanej noweli, że „prokurator może umorzyć śledztwo, jeżeli wniesienie oskarżenia do sądu byłoby niecelowe ze względu na znikome niebezpieczeństwo społeczne czynu" (§ 1). Artykuł 49 § 2 k.p.k. przewidywał, że po wniesieniu aktu oskarżenia postępowanie może być przez sąd ze wskazanej przyczyny umorzone na wniosek prokuratora ${ }^{6}$. Jeśli uświadomić sobie kontekst historyczny w postaci pogłębiającej się w owym czasie represji stalinowskiej ${ }^{7}$, wskazany przepis będący istotnym krokiem ku wprowadzeniu oportunizmu procesowego do postępowania karnego i dający prima facie szerokie pole do samodzielnej dyskrecjonalności prokuratora, wydaje się niemal kontrrewolucyjny.

6 Tekst jedn. z dnia 13.09.1950, Dz.U.1950.40.364.

7 Por. np. Prawo karne w okresie stalinizmu, red. G. Rejman, (,Studia Iuridica” 27), Warszawa 1995. Z późniejszych prac zwłaszcza Z.A. Ziemba, Prawo przeciwko społeczeństwu, Warszawa 1997; A. Lityński, Historia prawa karnego Polski Ludowej, Warszawa 2005; a także Komunistyczne prawo karne Polski Ludowej, red. A. Grześkowiak, Lublin 2007. 
Prawdopodobnie szybko dostrzeżono niebezpieczeństwo możliwej liberalnej wykładni prawa i wprowadzono stosowne korekty, zarówno w prawie, jak i w jego interpretacji. Kolejna nowela ${ }^{8}$ wprowadziła już brzmienie eksponujące obligatoryjność umorzenia, bliskie koncepcji materialnego ujęcia istoty przestępstwa, choć nadal procesowe i zasadniczo oportunistyczne. Nowy art. 49 k.p.k. stanowił: ,jeżeli niebezpieczeństwo społeczne czynu jest znikome, prokurator umarza śledztwo lub dochodzenie; po wniesieniu aktu oskarżenia postępowanie umarza sąd". Znacznie jaśniej intencje nowego prawa wykładała doktryna. Igor Andrejew i Jerzy Sawicki wskazywali, że „ustawodawca wprowadzając w art. 54 nowego k.p.k. [ostatecznie art. 49 - W.Z.], klasowe ujęcie przestępstwa nie wychodzi bynajmniej z założeń burżuazyjnego »oportunizmu« proceduralnego. Stanęliśmy raczej na stanowisku, że przy »znikomej szkodliwości społecznej« odpada istotny element przestępstwa, jego materialny substrat"9 . Autorzy definiowali przestępstwo, eksponując polityczno-kryminalną rolę oceny jego społecznego niebezpieczeństwa:

przestępstwem jest czyn ( $\mathrm{tj}$. działanie lub zaniechanie) człowieka, zawiniony, niebezpieczny dla mas pracujących Polski Ludowej i zabroniony pod groźbą kary przez ustawę obowiązująca w czasie jego popelnienia (zatem bezprawny i karalny), będący zamachem na podstawy ustrojowe Polski Ludowej, jej prawa, uznane prawem interesy jednostek, przedsiębiorstw państwowych lub spółdzielczych oraz organizacji lub stowarzyszeń oraz wszelkich osób prawnych w okresie przejściowym do socjalizmu ${ }^{10}$.

Równolegle postępowały prace nad nowym kodeksem karnym. Artykuły 1-3 projektu z 1951 roku nie pozostawiały złudzeń co do kierunku przewidywanej reformy. Wskazywano, że zadaniem polskiego ustawodawstwa karnego jest ochrona interesów Polski Ludowej i jej rozwoju ku socjalizmowi oraz wychowanie społeczeństwa w duchu praworządności ludowej, troskliwego stosunku do własności społecznej i przestrzegania zasad współżycia socjalistycznego. Artykuł 2 projektu stanowił, że przestępstwo jest to czyn społecznie niebezpieczny, zabroniony pod groźbą kary przez ustawę, popełniony z winy sprawcy. Dla jasności $\S 2$ art. 2 zawierał następującą definicję legalną: czynem społecznie niebezpiecznym jest zamach na polityczny lub gospodarczy ustrój Polski Ludowej, na jej suwerenność, na interesy Narodu, na władzę ludu pracującego, na budownictwo socjalistyczne w Polsce, na osoby obywateli i na ich prawa oraz na ludowy porządek prawny. Prymarnym zadaniem kary jest „unieszkodliwienie wrogów ludu pracującego" (art. $3 \S 1$ lit. a) ${ }^{11}$. Jak widać, prawo karne miało być instrumentem walki politycznej. Służyć zwalczaniu wrogów ustroju.

8 Dz.U.1955.46.309.

9 I. Andrejew, J. Sawicki, Istota przestępstwa w Polsce Ludowej. Kilka uwag z zakresu teorii prawa karnego, Warszawa 1949, s. 94. Warto odnotować, że I. Andrejew na okładce wskazanego działa podpisany jest jako dyrektor Centralnej Szkoły Prawniczej im. T. Duracza.

10 Ibidem.

11 Projekt kodeksu karnego Polski Ludowej. Część ogólna, Warszawa 1951, s. 3. 


\section{Marksistowsko-leninowskie tło materialnej treści przestępstwa i jego ocena w polskiej doktrynie prawa karnego w okresie międzywojennym}

Nie ulega wątpliwości, że owo marksistowskie ujęcie korespondowało z prawem radzieckim, w którym za klasykami marksizmu-leninizmu uznawano, że pojęcie przestępstwa jest pojęciem prawniczym historycznie zmiennym. Zgodnie z filozofią marksistowską prawo to instrument, za pomocą którego burżuazja definiuje i broni porządku kapitalistycznego, zwłaszcza zaś prawa własności. Przestępstwo zaś to owoc i manifestacja walki klasowej, która w komunizmie miała zniknąć $^{12}$. Jak wiadomo, według marksistów, głoszących materializm historyczny, państwo nie istniało wiecznie, było organizacją o charakterze historycznym, a więc przejściowym. W przeciwieństwie do anarchistów marksiści nie mówili o zniesieniu państwa, lecz jego „obumieraniu”. Obumieranie państwa oznaczało w ich pojęciu długotrwały i stopniowy proces, będący wynikiem rządzących społeczeństwem prawidłowości. Między anarchistami a marksistami widać więc istotną różnicę. Obumierać miało zaś jedynie państwo socjalistyczne ${ }^{13}$. Jednak zanim nastąpiło „obumarcie”, państwo radzieckie, zarządzane w pierwotnej fazie przez „dyktaturę proletariatu”, sięgało chętnie po instrumenty terroru.

Większość rządzących Radziecką Rosją bolszewików uważała, że rewolucja komunistyczna zniszczy państwo burżuazyjne i jego prawo, dając robotnikom wolność i możliwość samorządzenia bez ograniczeń prawa. Lider bolszewików Włodzimierz I. Lenin, był jednak politycznym realistą ${ }^{14}$ i zdawał sobie sprawę, że nowy reżim potrzebuje przynajmniej prawa publicznego. W krótkim czasie nowy reżim zaczął wykorzystywać prawo karne jako instrument walki, głównie $\mathrm{z}$,kontrrewolucją burżuazyjną" 15 . Terror rewolucyjny stosowano jawnie i niejawnie. Kodeks karny radziecki z 1922 i potem z 1926 roku odzwierciedlał rewolucyjne idee. Jak trafnie pisał J. Makarewicz:

kodeks rewolucyjny rosyjski, zwany kodeksem sowieckich republik przedstawia interes podwójny: z jednej strony interes czysto kryminalistyczny, jako dzieło pewnej, swoistej techniki kodyfikacyjnej, z drugiej strony jako przejaw współżycia społecznego i gospodarczego. Bronię zawsze tezy, że dla poznania rzeczywistego charakteru danego społeczeństwa, jego pojęć

12 Choć trzeba zaznaczyć, że teoria „kryminologicznego holizmu”, wizja konsensualnego i pacyfistycznego samodyscyplinującego się społeczeństwa komunistycznego to pomysł Lenina, a nie Marksa. W idealnym społeczeństwie komunistycznym ,indywidualne ekscesy” miały zniknąć; por. więcej L. Ferrajoli, D. Zolo, Marxism and the criminal question, „Law and Philosophy” 4, 1985 , nr 1, s. $80 \mathrm{n}$.

13 Por. R. Tokarczyk, Wspótczesne doktryny polityczne, Lublin 1984, s. 38-40.

14 Warto pamiętać, że W. I. Lenin był z wykształcenia prawnikiem, wykonującym nawet w latach 1891-1893 zawód adwokata; por. A. Bosiacki, U źródel „socjalizmu realnego”: koncepcja prawa wedtug Lenina, „Studia Iuridica” 35, 1998, s. 15 n.

15 Por. P.H. Solomon, Soviet Criminal Justice under Stalin, Cambridge 1996, s. 18-19. 
moralnych, jego zasad gospodarczych, jego ustroju, koniecznym jest zapoznanie się z jego kodeksem karnym. [...] Żadne deklamacje, żadna frazeologia nie zrównoważą wyraźnego, niedwuznacznego przepisu kodeksu karnego ${ }^{16}$.

$\mathrm{Z}$ radzieckich regulacji prawnokarnych przebijał natomiast cel w postaci deklaracji rewolucyjnej walki.

Kodeks sowiecki z 1926 roku w szczególny sposób ujmował definicję przestępstwa. Artykuł 6 stanowił: ,za przestępstwo poczytuje się wszelkie społecznie niebezpieczne działanie lub zaniechanie, zagrażające podstawom ustroju sowieckiego oraz porządkowi prawnemu, który przez Władzę Robotniczo-Włościańską został ustanowiony". W swym omówieniu prawa sowieckiego Juliusz Makarewicz stwierdzał trafnie, że to określenie było wyjątkowe. Dotąd kodeksy nie przesądzały istoty przestępstwa, lecz ograniczały się do rozwiązań technicznych: określenia poszczególnych typów przestępstw w części szczególnej i warunków, pod którymi można te przestępstwa ścigać, w części ogólnej. Autor pytał:

po co to określenie? Być może, że jest to brak znajomości zasad techniki ustawodawczej, która przestrzega przed wciąganiem do ustawy tego, co należy do literatury, być może jednak, że kryje się za tą pozorną ignorancją coś innego, a mianowicie szerokie zakreślenie możliwości stosowania kar, być może, że zasada art. 6 pozostaje w ścisłym związku z zasadą art. 10 , która wprowadza porzuconą w nowożytnych społeczeństwach zasadę analogii ${ }^{17}$.

Po kodeksie karnym radzieckim również inne ustawodawstwa przyjęły analogię w latach trzydziestych, na przykład Dania czy Niemcy. Przyjęcie analogii w prawie karnym to zazwyczaj (może poza Danią) krok w kierunku, lub objaw, totalitaryzmu.

Wprowadzenie analogii oznaczało zerwanie z zasadą nullum crimen sine lege. Jak wskazywał Makarewicz: „sądy sowieckie mają wielką swobodę w kwalifikowaniu czynów, nie potrzebują się krępować brzmieniem poszczególnych artykułów kodeksu, gdyż mają ogólną wskazówkę, co to jest przestępstwo i ustawowo zatwierdzoną swobodę ruchów"18. Zgodnie z art. 9 kary miały organa sądowe wymierzać ,według ich socjalistycznego poczucia prawnego z zachowaniem kierujących zasad i artykułów kodeksu". Stwierdzano jasno, że kodeks karny SSSR ma za zadanie ochronę prawną państwa ludzi pracy przed przestępstwami oraz czynnikami społecznie niebezpiecznymi (art. 5). Wynikało stąd, że prawo karne ma walczyć nie tylko z przestępstwami, że ma być nakierowane nie tylko na zwalczanie czynów wyczerpujących ich znamiona (lub znamiona podobne), lecz także ma zwalczać „,czynniki społecznie niebezpieczne”.

16 J. Makarewicz, Stowo wstępne, [w:] Kodeks karny republik sowieckich, Warszawa 1927, s. 7.

17 Ibidem, s. 10-11. Przepis art. 10 stanowił: „W razie braku w kodeksie karnym bezpośrednich wskazówek co do poszczególnych rodzajów przestępstw, wymierza się kary, względnie środki ochrony społecznej, zgodnie z artykułami kodeksu karnego, które przewidują przestępstwa najbardziej podobne co do doniosłości i rodzaju”.

18 Ibidem, s. 11-12. 
Nie można się nie zgodzić z tezą J. Makarewicza, że kodeks sowiecki z 1926 roku był kodeksem karnym o charakterze politycznym, rewolucyjnym, że w kodeksie tym ,uwaga ustawodawcy skierowana jest na tępienie ludzi o przeciwnym, niż panujący, poglądzie społecznym i prawnym" 19 .

W nauce polskiej prawa karnego $\mathrm{w}$ trakcie prac nad pierwszym polskim kodeksem karnym (1932 rok) zwyciężyło stanowisko, które lapidarnie wyraża następujące zdanie jednego z kodyfikatorów - Wacława Makowskiego: nie ma potrzeby słownikowego tłumaczenia wyrazu przestępstwo, który i tak będzie zrozumiały. Nie jest bowiem istotne dla ustawy doktrynalne określenie przestępstwa, lecz ustalenie normy prawnej, że za spełnienie czynu zabronionego pod groźbą kary sprawca ponosi karę ${ }^{20}$. Ostatecznie w ustawie przyjęto tak zwaną formalną definicję przestępstwa, która mówiła jedynie o tym, jakie zachowania zostają zaklasyfikowane jako przestępcze. Artykuł 1 k.k. z 1932 roku stanowił: odpowiedzialności karnej podlega ten, kto dopuszcza się czynu, zabronionego pod groźbą kary przez ustawę obowiązującą w czasie jego popełnienia. Definicja ta nie odpowiadała co prawda na pytanie, co stanowi o istocie przestępstwa oraz dlaczego te, a nie inne czyny zostały objęte kategorią przestępstw, nie była jednak negowana ${ }^{21}$. Mogło to pozornie dziwić, skoro większość ówczesnych karnistów deklarowało się po stronie socjologizmu Moderne Schule. Jak wiadomo, nurt ten, wywodzący się od Franza Liszta, przyjmował jego pogląd o konieczności „badania przestępstwa jako zjawiska społeczno-etycznego"22. Dostrzeganie istoty przestępstwa $\mathrm{w}$ jego antyspołecznym charakterze nie skutkowało jednak postulatami wprowadzenia materialnej treści do definicji przestępstwa. Jak konstatuje się współcześnie, jeśli chodzi o doktrynę prawa karnego, „,socjolog” F. Liszt ma więcej wspólnego z „klasykiem normatywistą” Karlem Bindingiem, niż jest między nimi w istocie różnic ${ }^{23}$. Znamienny jest tu pogląd Józefa Reinholda o dwóch definicjach przestępstwa. Autor ten uważał, że prawnik karnista zajmuje się jedynie rzeczywistością prawną, jest badaczem prawa pozytywnego, natomiast polityk kryminalny (kryminolog) bada wartości prawne, zajmuje się tym czym prawo powinno byćc ${ }^{24}$. Dwie płaszczyzny: prawną i kryminologiczną widział jasno J. Makarewicz, który pisał: „w regule kodeksy karne nie podają rodzajowego określenia przestępstwa [...] istota przestępstwa należy bowiem do dziedziny nauki, do filozofii prawa karnego" 25 .

19 Ibidem.

20 W. Makowski, Uwagi w sprawie koniecznych zmian i uzupetnień części ogólnej projektu kodeksu karnego, RPEiS 3, 1929, s. 246.

21 Por. M. Wąsowicz, Nurt socjologiczny w polskiej myśli prawnokarnej, Warszawa 1989, s. 144.

22 M. Cieślak, Polskie prawo karne, Warszawa 1995, s. 54.

23 Por. T. Vormbaum, [w:] M. Bohlander, T. Vormbaum, A Modern History of German Criminal Law, Berlin-Heidelberg 2014, s. 127.

24 J. Reinhold, Pojęcie i zakres polityki kryminalnej, „Czasopismo Prawne i Ekonomiczne” 19, 1921, s. 90 n.

25 Por. J. Makarewicz, op. cit., s. 10. 
Sięganie po omówienie kodeksu sowieckiego przy analizowaniu materialnej istoty przestępstwa w prawie polskim wydaje się usprawiedliwione. Nie jest jednak w pełni usprawiedliwione odwoływanie się do tradycji Moderne Schule, szlachetnych i pogłębionych analiz społecznej szkodliwości prowadzonych przez Cesare Beccarię i innych autorów. Nazwa ta sama lub bliska, ale treść i cel inny. Rację miał Janusz Kochanowski, który wskazywa1 ${ }^{26}$, że przyjęte w kodeksie z 1969 roku pojęcie „społecznego niebezpieczeństwa czynu” wywodzi się od niemieckiego teoretyka F. Liszta, związane jest ono jednak przede wszystkim $\mathrm{z}$ teorią i praktyką prawa radzieckiego, pod wpływem tego prawa i jego ideologii zostało wprowadzone do polskiego ustawodawstwa karnego. Charakterystyczne, że takie właśnie rozróżnienie wprowadzał u schyłku naukowej kariery, a zarazem u progu transformacji ustrojowej w Polsce sam Igor Andrejew:

mimo wpływów szkoły socjologicznej na prawo radzieckie, w pierwszym okresie jego istnienia trudno jest powiązać koncepcję „społecznego niebezpieczeństwa czynu” z twórczością Liszta lub innego teoretyka szkoły socjologicznej. [...] Jego podniesienie do rangi doniosłej instytucji należy thumaczyć przekonaniem o potrzebie w budowie nowego, rewolucyjnego prawa karnego 27 .

Autor dokonał rewizji swoich wcześniejszych poglądów, o czym dalej.

\section{Groźba zniesienia zakazu analogii na niekorzyść sprawcy}

Wracając do krytycznego dla prowadzonych rozważań okresu lat 1949-1955, należy zauważyć, że wprowadzenie analogii do polskiego prawa karnego na wzór radziecki było wówczas bardzo realne. W owym czasie wprowadzono ją do wielu ustawodawstw socjalistycznych, w tym do kodeksów karnych: bułgarskiego, albańskiego, rumuńskiego, chińskiego oraz koreańskiego. Ważyły się losy analogii w prawie polskim. Charakterystyczne, że w drugim wydaniu klasycznego podręcznika początków PRL $^{28}$ pisano, że analogia w państwie socjalistycznym jest inna, lepsza, albowiem ustawodawstwo socjalistyczne ,wyraża wolę ludu pracującego”. W ustawodawstwie tym „dobrze pojęta analogia może być w ręku sędziego korekturą ustawodawstwa karnego, zgodną ze świadomością prawną mas pracujących”. Autorzy wskazywali, że ,analogia w naszych warunkach może [...] potwierdzać i umacniać praworządność ludową"29.

26 Por. J. Kochanowski, Przeciwko pośpiesznej kodyfikacji karnej, „Palestra” 1990, nr 8-9, s. 15.

27 I. Andrejew, Podstawowe pojęcia nauki o przestępstwie, Warszawa 1988, s. 102-103.

28 Por. I. Andrejew, L. Lernell, J. Sawicki, Prawo karne Polski Ludowej. Wiadomości ogólne, Warszawa 1954, s. 326.

29 Por. ibidem. 
Trafnie konkluduje się, że „prominentni profesorowie-marksiści, specjaliści od prawa karnego, Igor Andrejew, Leszek Lemell i Jerzy Sawicki, dopuszczali możliwość stosowania analogii na niekorzyść sprawcy w prawie karnym materialnym. Dokładnie tak jak w Związku Sowieckim i Niemczech Hitlera..." ${ }^{30}$. Można spekulować, które wydarzenia przeszkodziły w procesie wprowadzania analogii na niekorzyść do polskiego prawa. Z pewnością znaczenie miała śmierć Józefa Stalina w 1953 roku, ale decydować musiały również inne czynniki, jak choćby obawa przed oporem sędziów wychowanych jeszcze w wolnej Polsce ${ }^{31}$. Wszakże śmierć Wielkiego Przywódcy nie przeszkodziła w posługiwaniu się analogią na przykład w Chińskiej Republice Ludowej do końca XX wieku, o czym dalej.

Zaskakują paralele dwóch totalitaryzmów w podejściu do wymiaru sprawiedliwości.

Znaczenie analogii w kontekście ocen społecznej szkodliwości czynu w prawie Niemiec hitlerowskich jest w Polsce mniej rozpoznane, ale warto poświęcić mu chwilę uwagi. Prawo karne w Niemczech poddane zostało podobnemu do radzieckiego procesowi instrumentalizacji z hipokrytycznym zachowaniem pozorów. Znamienne jest odwoływanie się przez przywódców i legislatorów do moralności. Sam Adolf Hitler twierdził, że „państwo totalne nie ścierpi różnicy między prawem a moralnością"32. Granica między prawem a moralnością została więc zatarta. Moralne miało być to, co zostało nakazane przez prawo, albowiem wszelkie zachowania społeczne miały być kształtowane albo wyzyskiwane przez państwo. Następstwem było powszechne stosowanie prawa karnego. Najważniejsza w omawianym kontekście okazała się nowela StGB z 28 czerwca 1935 roku. Nowy $\S 2$ kodeksu wprowadzał zasadę, aby w miejsce dotychczasowego formalnego pojęcia bezprawia wprowadzić pojęcie bezprawia materialnego (Die materielle Rechtswidrigkeit). Odtąd podstawą ścigania miało się stać nie tylko prawo stanowione, ale także zdrowe ludowe poczucie sprawiedliwości (gesundes Volksempfinden $)^{33}$. Zmiana ta oznaczała odejście od zasady nullum crimen sine lege.

Nazistowska poprawka o analogii z 1935 roku trafiła w samą istotę nowożytnego prawa karnego materialnego. Miała na celu ,przesunięcie o krok dalej dostosowania prawa karnego do ducha nowego państwa”. Artykuł 1 dopuszczał „analogiczne stosowanie przepisów karnych”, art. 2 zaś Wahlfeststellung, czyli wyrok alternatywny, w przypadkach niejasnych co do tego, które z szeregu przestępstw popełnił oskarżony. Wskazuje się, że ustawa ta mocno ugruntowała

30 Tak M. Zaborski, [rec.] „Prawo karne w okresie stalinizmu”, pod red. nauk. Genowefy Rejman, Warszawa 1995, „Palestra” 40, 1996, nr 3-4, s. 215.

31 G. Jakubowski, Sadownictwo powszechne w Polsce w latach 1944-1950, Warszawa 2002, s. $57 \mathrm{n}$.

32 Por. F. Ryszka, Państwo stanu wyjątkowego. Rzecz o systemie państwa i prawa III Rzeszy, Wrocław 1985, s. 472. Zdanie wygłoszone na Zjeździe Prawników (Rechtswahrertag) w październiku 1936 r.

33 Por. ibidem, s. 472-476. 
materialną definicję przestępstwa. Traktuje się ją jako materialnoprawny odpowiednik proceduralnego terminu ustalenia prawdy materialnej. Zawsze istnieje możliwość, że prawa, które są ogólne i abstrakcyjne, ale precyzyjnie sformułowane, w poszczególnych przypadkach będą strzelać „poza cel”. Liberalne rozumienie prawa karnego uspokaja te wątpliwości, zauważając, że zasada nullum crimen sine lege może skutkować jedynie niesprawiedliwością na korzyść oskarżonego obywatela. Jak trafnie wskazuje Thomas Vormbaum:

Jeśli jednak prawo karne kieruje się całkowicie materialną koncepcją sprawiedliwości, która jest określana na nowo w każdym indywidualnym przypadku, wówczas idea sędziego musi się odpowiednio zmienić [...]: sędzia nie jest już sługą sprawiedliwości, ale jego twórcą; staje się $[\ldots]$ wyrozumiałym partnerem ustawodawcy ${ }^{34}$.

Materialna koncepcja sprawiedliwości była propagowana przez nazistowskich działaczy i praktyków prawa karnego, takich jak Hans Frank, Roland Freisler czy Karl Siegert. W swoim przemówieniu otwierającym XI Międzynarodową Konferencję Prawa Karnego i Więziennictwa w 1935 roku minister sprawiedliwości Rzeszy Franz Gürtner opowiedział się za zastąpieniem formalnej legalności i definicji przestępstwa materialną koncepcją bezprawności, której treść miała zostać określona przez sędziów na podstawie „wymogów życia ludu” i ,zasady prymatu Führera”. Czołowy urzędnik ministerstwa pisał o „przełomie” (Durchbruch) w postaci materialnej koncepcji sprawiedliwości. Interesujące jest, że znaczący przedstawiciele nauki byli gotowi zaakceptować te zmiany. W 1934 roku Edmund Mezger odwoływał się do „totalnego rozumienia państwa” i „totalnej jedności prawa”, odróżniając je od przestarzałego „pojmowania liberalnego”. Zasada legalizmu staje się „kwestią celowości”, „umiarkowane złagodzenie” zaś zakazu analogii nie budzi jego ,znaczących obaw”. Hans Welzel, skądinąd antagonista Mezgera, też przejawiał sympatię dla nazistowskiego etatyzmu w sprawie prawa karnego. Friedrich Schaffstein propagował ów „materializm” narodowosocjalistyczny i „państwo totalne”, w którym „dążenie jednostki do pewności prawa” jest drugorzędne w stosunku do „dążenia do materialnej sprawiedliwości”, rozumianego jako dążenie do odzyskania jedności prawa karnego i porządku moralnego. Koncepcja przestępstwa łączy się z koniecznością zniesienia zakazu analogii, celem jest bowiem przezwyciężenie formalnych ograniczeń pozytywi$\mathrm{zmu}^{35}$. Dążono do zastąpienia zasady nullum crimen sine lege zasadą nullum crimen sine poena, albowiem wszystkie przestępstwa groźne dla państwa powinny być ukarane.

Wskazane myślenie, akceptowane przez czołowych prawników niemieckich, mogło zostać zmienione dopiero przez procesy norymberskie zbrodniarzy faszystowskich, denazyfikację, zmiany litery prawa (przywrócenie zasady zakazu

34 T. Vormbaum, op. cit., s. 182-193.

35 Por. omówienie poglądów czołowych karnistów niemieckich w K. Ambos, National Socialist Criminal Law. Continuity and Radicalization, Baden-Baden 2019, s. $41 \mathrm{n}$. 
analogii Analogieverbot ${ }^{36}$ ), a także zmiany filozofii i postrzegania prawa przez samych prawników, przez tak zwane drugie odrodzenia prawa natury, w tym za sprawą Gustawa Radbrucha ${ }^{37}$.

Tymczasem w ustawodawstwie radzieckim analogię zniesiono dopiero w 1958 roku. Zakaz analogii wprowadzono mocą art. 3 Podstaw ustawodawstwa karnego ZSRR i Republik Związkowych z 25 grudnia 1958 roku $^{38}$. W kolejnych latach, aż do 1961 roku, znosiły ją kolejne republiki związkowe ZSRR. Widać stąd, że obawa o wprowadzenie jej do tego czasu w prawie polskim była całkiem realna.

Zmiana w prawie radzickim nie oznaczała zmiany w tym zakresie na całym świecie. Znamienne, że analogię w prawie chińskim zniesiono dopiero reformą z 1997 roku. Przewidywał ją do tego czasu art. 79 k.k. z 1979 roku, stanowiący, że przestępstwa, które nie zostały wyraźnie zdefiniowane w k.k. ChRL: „mogą być ustalane i karane zgodnie z jakimkolwiek artykułem [...], który obejmuje najbardziej podobne przestępstwo". Wyroki oparte na tym przepisie wymagały zatwierdzenia przez Sąd Najwyższy. Wskazuje się, że w czasie obrad nad k.k. z 1979 roku istniało poparcie dla przyjęcia zasady analogii, ze względu na potrzebę zachowania elastyczności w świetle szybko zmieniających się warunków gospodarczych i społecznych w Chinach. Taka polityka była skorelowana z koniecznością zapewnienia zwiększonej kontroli politycznej i społecznej. W praktyce problemy związane $\mathrm{z}$ dopuszczeniem ścigania przestępstw $\mathrm{w}$ drodze analogii były potęgowane przez niewykwalifikowany personel wymiaru sprawiedliwości. Zniesienie analogii poprzedziły zmiany polityczne. Jiang Zemin formalnie poparł reformę w swoich wystąpieniach we wrześniu 1997 roku, zapowiadając ,prowadzenie kraju zgodnie z prawem i ustanowienie socjalistycznego państwa prawa”. Wskazuje się jednak, że zniesienie analogii, strzeliste deklaracje polityczne, a nawet zmiana konstytucji ChRL z 1999 roku nie oznaczały wprowadzenia de facto rządów prawa. Przyjęcie zasady nullem crimen sine lege i nulla poena sine lege należy oceniać na przykład w świetle podziału prawa karnego i administracyjnego, a zwłaszcza stosowania kar administracyjnych ${ }^{39}$.

Wątek przesuwania represji państwowej w stronę prawa administracyjnego, przy jednoczesnym zachowywaniu pozorów praworządności na gruncie prawa karnego, jest niezwykle aktualny i wymaga osobnego omówienia ${ }^{40}$.

36 Więcej o tym Ch. Fitting, Analogieverbot und Kontinuität. Entwicklungslinien des strafrechtlichen Analogieverbots seit 1871, Berlin 2016.

37 Por. J. Zajadło, Formuła Radbrucha, Gdańsk 2001; idem, Dziedzictwo przeszłości. Gustaw Radbruch: portret filozofa, prawnika, polityka i humanisty, Gdańsk 2007, s. 210 n.

38 A. Marek, Stopień społecznego niebezpieczeństwa czynu jako podstawa umorzenia postępowania karnego, Torun 1970, s. 25.

39 Por. I. Dobinson, The Criminal Law of the People's Republic of China (1997): Real change or rhetoric?, „Washington International Law Journal” 11, 2002, nr 1, s. 26 n. Autor analizuje między innymi sposób postępowania z członkami sekty Falun Gong.

40 Por. np. Administratywizacja prawa karnego czy kryminalizacja prawa administracyjnego?, red. M. Bogusz, W. Zalewski, Gdańsk 2021. 
Do końca ZSRR istniała w Podstawach odpowiedzialności karnej mieszana definicja przestępstwa odwołująca się do pojęcia społecznego niebezpieczeństwa. Otóż przestępstwem był:

przewidziany przez ustawę karną społecznie niebezpieczny czyn (działanie lub zaniechanie) wymierzony przeciwko radzieckiemu społecznemu lub państwowemu ustrojowi, socjalistycznemu systemowi gospodarczemu, mieniu społecznemu, osobom, a także politycznym, pracowniczym, majątkowym, i innym prawom obywateli, a także inne wymierzone przeciwko porządkowi socjalistycznemu czyny społecznie niebezpieczne przewidziane przez prawo ${ }^{41}$.

Również obowiązujący obecnie kodeks karny Federacji Rosyjskiej z 13 czerwca 1996 roku zawiera mieszaną formalnomaterialną definicję przestępstwa, art. 14: „za przestępstwo uważa się czyn społecznie niebezpieczny, zawiniony i zabroniony przez niniejszy Kodeks pod groźbą kary”. W ust. 2 znajduje się odwołanie do materialnej treści ujęte tak: „nie będzie uważane za przestępstwo działanie (lub zaniechanie działania), formalnie zawierające znamiona jakiegokolwiek czynu przewidzianego w niniejszym Kodeksie, które jednak ze względu na swoją nieistotność [но в силу малозначительности] nie stanowi niebezpieczeństwa społecznego" ${ }^{42}$. Paraleli między kodeksem karnym rosyjskim z czerwca 1996 i polskim kodeksem karnym z czerwca 1997 roku jest więcej ${ }^{43}$.

Podsumowując początki społecznej szkodliwości w prawie europejskim (radzieckim, faszystowskim, państwach komunistycznych po drugiej wojnie), dostrzec można pewne paralele. Wprowadzano ją celem instrumentalizacji prawa karnego, do zapewnienia skutecznej realizacji zakładanych celów politycznych. Wprowadzaniu społecznej szkodliwości (odpowiednio materialnej sprawiedliwości, bezprawności) towarzyszyło podważanie zasady określoności prawa karnego i formalizmu gwarantującego wolności obywatelskie. Kodeks karny przestawał być postrzegany jako magna carta wszystkich podejrzanych i oskarżonych, albowiem karanie przestępców — wrogów było celem nadrzędnym. Dopełnieniem procesu było wprowadzenie analogii na niekorzyść sprawcy.

41 Por. M. Filar, W stużbie utopii. 73 lata radzieckiego prawa karnego, Torun 1992, s. 43.

42 „Статья 14. Понятие преступления 1. Преступлением признается виновно совершенное «общественно опасное деяние», запрещенное настоящим Кодексом под угрозой наказания. 2. Не является преступлением действие (бездействие), хотя формально и содержащее признаки какого-либо деяния, предусмотренного настоящим Кодексом, но в силу малозначительности не представляющее общественной опасности. (в ред. Федерального закона от 25.06.1998 N 92-Ф3) «Уголовный кодекс Российской Федерации» от 13.06.1996 N 63-Ф3 (ред. от 08.12.2020)".

43 Wystarczy wskazać na przykład zasadę humanizmu - art. 7 k.k. FR i art. 3 k.k. k.k. RP. Por. więcej W. Zalewski, komentarz do art. 3 k.k., [w:], Kodeks karny komentarz, red. M. Królikowski, R. Zawłocki, t. 1, Warszawa 2017. 


\section{Materialna definicja przestępstwa w PRL i w początkach transformacji ustrojowej po 1989 roku. Spory o reformę, stan obecny, postulaty zmian}

Wprowadzanie materialnej definicji przestępstwa w Polsce przebiegało z pewnymi oporami. Jak wskazano, społeczne niebezpieczeństwo wprowadzono do polskiego prawa karnego prawem procesowym w dwóch fazach. Ustawą z 1949 roku wprowadzono je do k.p.k. Uzasadnienie projektu ustawy mówiło $\mathrm{w}$ związku z tym przepisem o zasadzie oportunizmu prokuratorskiego ${ }^{44}$. Przepis art. 49 k.p.k. w pierwotnym kształcie nie powinien budzić wątpliwości, gdyż wiele współczesnych ustawodawstw posługuje się procesową zasadą oportunizmu bądź jako główną, bądź jako wyjątkiem od legalizmu. W praktyce na przykład belgijskich prokuratur wzgląd na błahy charakter przestępstwa jest jedną z przesłanek oportunizmu ${ }^{45}$. Stało się jednak inaczej. W art. 49 po kolejnej noweli z 1955 roku widziano przede wszystkim nowe, klasowe ujęcie przestępstwa ${ }^{46}$. Jak już dwa lata wcześniej wyjaśnił Marian Cieślak, nie chodzi o to, by prokurator oceniał celowość ścigania, ale by oceniał materialną istotę czynu ${ }^{47}$. Odtąd twierdzenie o społecznej szkodliwości jako elemencie przestępstwa wydawało się przesądzone. Doktryna była jednak oporna i jeszcze w latach sześćdziesiątych niekiedy przyjmowała, że brak materialnej treści nie wyklucza przestępności, lecz „czyn nadal jest przestępstwem, ale ściganie karne nie następuje wobec zachodzącej ujemnej przesłanki procesowej" ${ }^{48}$. Podobnie SN jeszcze w 1961 roku wyjaśniał, że z treści art. 49 wynika, że umorzenie postępowania ze względu na znikome społeczne niebezpieczeństwo czynu nie jest jednoznaczne z uniewinnieniem sprawcy. Jego czyn wypełnia przedmiotowe i podmiotowe znamiona przestępstwa, a jedynie

44 Por. A. Marek, op. cit., s. 91.

45 Por. A. Wąsek, Wprowadzenie do belgijskiego prawa karnego, Warszawa 1995, s.73 n.

46 Zapowiadano tę zmianę już wcześniej, por. I. Andrejew, J. Sawicki, Istota przestęstwa w Polsce Ludowej, Warszawa 1951, s. 94.

47 M. Cieślak, Proces karny, cz. 2, Kraków 1953, s. 119.

48 Tak M. Siewierski, Przegląd orzecznictwa SN, „Państwo i Prawo” 1964, nr 12, s. 916. Podobnie wcześniej H. Rajzman, Sprawa wykładni, wytycznych czy ustawy, „Państwo i Prawo” 1958, nr 8-9, który twierdził, że „orzeczenie na mocy art. 49 k.p.k. ma cechy pociągnięcia rzędu abolicyjnego". Warto odnotować, że Mieczysław Siewierski był przed wojną prokuratorem Sądu Najwyższego. Za swą działalność przedwojenną został w 1950 roku aresztowany. Zarzucono mu, że ,jako przedwojenny prokurator oskarżał w procesach działaczy komunistycznych, oraz wyznaczał sędziów do pracy w komisjach wyborczych w wyborach na »mocy konstytucji faszystowskiej« z 1935 roku"; por. więcej J. Kita, S. Pytlas, Profesorowie Uniwersytetu Łódzkiego 1945-1994. Pro Memoria, Łódź 1995, s. 183-185; E. Romanowska, Prokurator z pasja, „W Sieci historii” 2020, nr 7-8, s. 61. Wcześniej przeciwko wprowadzeniu społecznego niebezpieczeństwa czynu do prawa polskiego wypowiedział się Marek Olszewski, Czy utrzymać pojęcie społecznego niebezpieczeństwa czynu w prawie karnym, „Państwo i Prawo” 1958, nr 3, s. 425 n. 
interes społeczny nie wymaga ukarania go w danym wypadku ${ }^{49}$. Zwolennicy społecznej szkodliwości jako elementu przestępstwa wywodzili natomiast, że jeżeli ma następować umorzenie z powodu znikomej społecznej treści, to może to następować tylko wtedy, gdy nie ma przestępstwa. W przeciwnym razie, to jest wtedy, gdy przyjmie się przestępstwo, umorzenie będzie sprzeczne z zasadą legalizmu, będzie ukrytym oportunizmem ${ }^{50}$. Zasada oportunizmu daje, jak wiadomo, jawnie swobodę organom stosującym prawo oceny celowości ścigania w danym wypadku. Nie podlega dyskusji, że w państwie autorytarnym ta swoboda winna być jak najmniejsza. W państwie deklarującym socjalistyczną sprawiedliwość i humanizm nie można sobie było na to pozwolić.

Wobec tego, że w prawie polskim, w zasadzie, respektowano zasadę nullum crimen sine lege, wcześniej omówiona „pozytywna” rola zasady społecznego niebezpieczeństwa, związana z między innymi typizacją per analogiam pełnioną na przykład w prawie radzieckim, nie występowała. Większą rolę odgrywało i odgrywa nadal bardziej przydatne ujęcie społecznej szkodliwości od strony negatywnej ${ }^{51}$. W tym ujęciu materialna treść przestępstwa prowadziła do rezygnacji przez prawo karne z zainteresowania czynami, które zawierają tylko formalne znamiona przestępstwa, nie mają natomiast dostatecznego elementu materialnego. Zainteresowanie to, jak pisała słusznie Oktawia Górniok, deprecjonuje wymiar sprawiedliwości, absorbuje jego czas i wysiłki, a ponadto nie pozwala się skoncentrować na zwalczaniu czynów typowo społecznie niebezpiecznych ${ }^{52}$. Następuje więc umorzenie postępowania w takich sprawach, tyle że na podstawie braku przestępstwa, a nie na podstawie celowości ścigania, która jest jego istotą.

Wprowadzenie materialnej definicji przestępstwa do k.k. z 1969 art. 1 zdaniem niektórych podważyło zasadność istnienia w kodeksie odrębnie stypizowanych okoliczności wyłączających winę i bezprawność. Jak pisał Jerzy Smoleński, umieszczenie w kodeksie prawidłowo skonstruowanej materialnej definicji przestępstwa czyni bezprzedmiotowym formułowanie w nim jakichkolwiek kontratypów. Wprowadzenie ich do kodeksu da się uzasadnić tylko względami praktycznymi w sensie ułatwienia oceny pewnych sytuacji typowych ${ }^{53}$. Doszło do ciekawej dyskusji, w której na przykład Adam Krukowski wypowiedział pogląd, że brak społecznej szkodliwości jest cechą wszystkich kontratypów. Dotyczy zarówno konkretnego wypadku o takiej charakterystyce społecznej, jak i typu zachowania, stąd należy włączyć do kontratypów znikome społeczne niebezpieczeństwo ${ }^{54}$.

49 OSPiKA 1961, z. 12, VI Ko. 3/59.

50 Przegląd stanowisk A. Marek, op. cit., s. 96 n.

51 O. Górniok, Czyny o niktym niebezpieczeństwie społecznym, „Nowe Prawo” 1963, nr 7-8, s. 788.

52 Ibidem.

53 J. Smoleński, Problematyka materialnej istoty przestępstwa $w$ projekcie k.k., „Państwo i Prawo" 1963, nr 8-9.

54 A. Krukowski, Materialna treść przestępstwa a okoliczności wyłączające odpowiedzialność karna, „Nowe Prawo” 1971, nr 12, s. 1769. 
Jego oponenci twierdzili, że cechą kontratypu jest typowość, a cecha materialnej ujemności wynika z różnych, często nietypowych, okoliczności ${ }^{55}$.

W okresie obowiązywania k.p.k. po reformie z 1949 i k.k. z 1969 roku społeczne niebezpieczeństwo było przedmiotem nieustannych sporów, licznych wypowiedzi orzecznictwa i doktryny ${ }^{56}$. Ostatecznie wykrystalizowały się trzy ujęcia: przedmiotowe, podmiotowo-przedmiotowe i uniwersalne ${ }^{57}$. Apogeum sporów przypadło na lata dziewięćdziesiąte, kiedy to podważano sens istnienia tej przesłanki odpowiedzialności karnej ${ }^{58}$.

Często podkreśla się, że kodeks karny z 1997 roku powstał w istocie bez zaktualizowanych założeń ogólnych. Komisja kodyfikacyjna, powołana w dniu 14 maja 1987 roku przez premiera Zbigniewa Messnera, rozpoczęła prace 26 października 1987 roku. Zasadność decyzji o jej powołaniu zdążyło jeszcze potwierdzić VII plenum KC PZPR. W dokumencie Założenia reformy ustawodawstwa karnego z 28 lipca 1988 roku wskazano, że reforma ma służyć ,,procesom socjalistycznej odnowy", jej celem miało być zharmonizowanie przyjętej polityki kryminalnej $\mathrm{z}$,ideałami humanizmu socjalistycznego" oraz z „pryncypiami ustrojowymi" ${ }^{59}$.

W ostatnich miesiącach 1989 roku, a więc już po rozpoczęciu transformacji ustrojowej, dokonano w Komisji zmian personalnych, jednak jej przewodniczącym, przez cały okres prac, pozostał prof. Kazimierz Buchała, natomiast na zastępcę powołano prof. Andrzeja Zolla. Komisja ds. reformy prawa karnego materialnego liczyła ostatecznie 23 członków, z czego 10 osób to pracownicy nauki. Wbrew oczekiwaniom nie opracowano jednak nowych założeń projektu, zgodnych ,z pryncypiami” liberalnego państwa demokratycznego. Nie opublikowano też protokołów prac, co powoduje, że przebiegu prac można się jedynie

55 Np. T. Bojarski, W sprawie funkcji art. 26 k.k., „Palestra” 1971, nr 4. Por. więcej W. Wolter, Nauka o przestępstwie, Warszawa 1973, s. 258.

56 Por. przegląd stanowisk u progu k.k. 1969 r. przede wszystkim T. Kaczmarek, Materialna istota przestęstwa i jego ustawowe znamiona, Wrocław 1968; ze współczesnych wypowiedzi zwięzła prezentacja poglądów w M. Gałązka, Społeczne niebezpieczeństwo czynu w komunistycznym prawie karnym Polski Ludowej, [w:] Komunistyczne prawo karne..., s. 135-186.

57 Por. omówienie tych ujęć R. Zawłocki, Pojęcie i funkcje społecznej szkodliwości czynu w prawie karnym, Warszawa 2007, s. $125 \mathrm{n}$.

58 Por. M. Filar, O niektórych ogólnych zasadach odpowiedzialności karnej w projekcie Kodeksu karnego z sierpnia 1990 r. - polemicznie, „Państwo i Prawo” 1991, nr 4, s. 80 n.; idem, O niektórych ogólnych zasadach odpowiedzialności karnej w projekcie Kodeksu karnego z sierpnia 1990 r. - polemicznie, [w:] Problemy reformy prawa karnego, red. T. Bojarski, E. Skrętowicz, Lublin 1993; W. Mącior, Der Begriff und die Bedeutung der gesellschaftlichen Gefährlichkeit der Tat im polnischen Strafgesetzbuch von 1969, „Recht in Ost und West” 1989, z. 1; idem, Negatywny wplyw marksizmu na polska naukę prawa karnego, „Palestra” 1990, nr 8-9, s. 19 n.; idem, W sprawie reformy prawa karnego, „Państwo i Prawo” 1991, z. 10, s. 89 n.; J. Kochanowski, op. cit.

59 Por. K. Daszkiewicz, op. cit., s. 7. 
domyślać na podstawie rozsianych w różnych tekstach fragmentów wypowiedzi członków Komisji ${ }^{60}$.

Marian Filar zwrócił uwagę na immanentną cechę społecznej szkodliwości - ocenę utylitarną. Brak ujemności jest wynikiem stosowania prawa z uwzględnieniem indywidualnej oceny polityczno-kryminalnej. Brak typowości tych sytuacji powoduje jednak niepewność, a niekiedy dowolność w prawie ${ }^{61}$. I to dowolność niejawną, nieopartą na oportunizmie w ściganiu, lecz na przyjęciu, że to, co w jednym miejscu ze względu na warunki lokalne jest przestępstwem, w innym, z powodu innych uwarunkowań, nie jest przestępstwem. Nie może być tak, żeby byt sam przestępstwa uwarunkowany był oceną celowości ścigania. Przestępstwo jest ogólnym bytem normatywnym, kreowanym ustawą ${ }^{62}$. M. Filar, jak wskazano, domagał się rezygnacji z instrumentalnego traktowania pojęcia przestępstwa. Uważał, że nie należy sięgać do twierdzenia o braku przestępczości tam, gdzie wystarczy zastosowanie oportunizmu w ściganiu.

Odmiennie widzi to A. Zoll, wskazując, że ustawodawca zakłada, iż opis czynu zabronionego, ze względu na swój generalny i abstrakcyjny charakter, może trafić „poza cel” 63 obejmujący zachowania, które z uwagi na cechy indywidualne czynu nie są karygodne ${ }^{64}$. Twierdzenie o „strzale poza cel” jako częściowo chybionej formie kryminalizacji nie jest łatwe do przyjęcia. Oznacza to, że ustawodawca nieudolnie określił ramy typu czynu zabronionego, obejmując nim zachowania społecznie nieniebezpieczne. Pytanie: czy zadaniem sądu jest dokonywanie korektur? Czy sędzia ma być „,wyrozumiałem współtwórcą prawa”, tyle że w sensie negatywnym? Dla A. Zolla określony stopień społecznej ujemności jest uzasadnieniem potraktowania konkretnego czynu jako przestępstwa. Autor wskazuje, że jeśli ujemna zawartość czynu będzie atypowo niska, to będzie brakować uzasadnienia potraktowania tego czynu jako przestępstwa ${ }^{65}$. Brak uzasadnienia traktowania jednostkowego czynu jako przestępstwa jest niczym innym jak stwierdzeniem niecelowości karania w danym wypadku, przy jednoczesnym stwierdzeniu bezprawności. Ujmując rzecz prościej: czyn jest formalnie bezprawny, jednak nie zasługuje na karę (jest niekarygodny), więc nie jest przestępstwem. Czy takie rozumowanie i wynikające zeń działanie jest racjonalne w państwie praworządnym?

60 Por. K. Daszkiewicz, op. cit., s. 7-9. A. Zoll wskazywał, że prace Komisji są protokołowane i że „może w przyszłości będą także warunki do ich opublikowania”, idem, Spójrzmy inaczej, „Wokanda” 1990, nr 28, s. 4.

61 Por. np. M. Szerer, Karanie a humanizm, Warszawa 1964, który wskazywał, że omawiane pojęcie jest „tak szerokie, że przestaje być użyteczne”.

62 Por. M. Filar, O niektórych ogólnych zasadach odpowiedzialności karnej w projekcie Kodeksu karnego z sierpnia 1990 r. — polemicznie, [w:] Problemy reformy..., s. 19.

63 Sformułowanie W. Woltera, Prawo karne, Warszawa 1947, s. 130.

64 Por. A. Zoll, Zasady odpowiedzialności karnej, „Nowa Kodyfikacja Karna. Kodeks karny” 1998, z. 12, s. 13.

65 Por. ibidem. 
Rację ma M. Filar, gdy pyta, czy podobny czyn, który wyczerpuje cechy istoty danego typu opisane w ustawie: „w Krakowie może być przestępstwem, a w Toruniu nie?"66. Czy takie rozważania nie prowadzą na manowce? Jak bardzo by zaprzeczać, że oceny społecznej szkodliwości (niebezpieczeństwa) należy dokonywać in concreto, a nie in abstracto ${ }^{67}$, zawsze powstają wątpliwości co do racjonalności kryminalizacji in genere, na poziomie ustawowym. Potwierdzili to współautorzy nowego kodeksu karnego, wskazując, że im niższy stopień ujemnej zawartości przypisywany typowi, tym większa szansa, że zachowania realizujące znamiona tego typu będą w znikomym stopniu społecznie niebezpieczne ${ }^{68}$. Innymi słowy: ,prawdopodobieństwo dokonania jednostkowego ustalenia przez sąd minimalnej ujemnej zawartości czynu jest odwrotnie proporcjonalne do stopnia społecznego niebezpieczeństwa odnoszonego do typu"69. Jeśli zdanie to jest prawdziwe, nie sposób negować istnienia związku między brakiem społecznego niebezpieczeństwa czynu jednostkowego a społecznym niebezpieczeństwem typu. Ostatecznie mnogość na przykład umorzeń jednostkowych w przypadku danego typu czynu zabronionego wskazuje zazwyczaj, że typ „trafił poza cel”. Ilość może przejść w jakość. Ową dialektyczną zależność widzą autorzy, skoro piszą: ,może się zdarzyć, że ten stopień jest już tak niski, że gdyby dokonać jego generalizacji, to odpadłyby podstawy do kryminalizacji zachowań" ${ }^{\text {"70 }}$. A jeśli i to jest prawdą, to wartość twierdzenia, że zasada nullum crimen sine lege periculo sociali odnosi się wyłącznie do ustawodawcy, jest wątpliwa na gruncie polskiego prawa. Stwierdzenie braku przestępstwa nie jest stwierdzeniem, że dany typ nie obejmuje danego wypadku. Społeczna szkodliwość nie jest znamieniem typu. Jest treścią zespołu znamion ${ }^{71}$. Odnosi się do oceny celowości zastosowania sankcji do danego wypadku. Oceny karygodności, czyli słownikowo: zasługiwania na $\operatorname{karę}^{72}$, jest kryterium pozanormatywnym, od ustawodawcy niezależnym. Normatywny charakter może mieć jedynie obowiązek, bezwzględny lub względny,

66 Por. M. Filar, O niektórych ogólnych ..., „Państwo i Prawo”, s. 80 n.

67 Por. A. Zoll, Zasady odpowiedzialności karnej. Konsekwentnie także w innych tekstach: A. Zoll, Ogólne zasady odpowiedzialności karnej w projekcie kodeksu karnego, „Państwo i Prawo” 1990, nr 10, s. 30 n.; idem, O reformie prawa karnego (w odpowiedzi W. Maciorowi), „Państwo i Prawo" 1992, nr 1, s. 95 n.; idem, Materialne okré́lenie przestępstwa w projekcie kodeksu karnego, [w:] Problemy kodyfikacji prawa karnego. Księga ku czci Profesora Mariana Cieślaka, Kraków 1993, s. 85 n.; idem, Materialne określenie przestępstwa, „Prokuratura i Prawo” 1997, nr 2, s. 10 n.; oraz idem, [w:] K. Buchała, A. Zoll, Kodeks karny. Część ogólna. Komentarz do art. 1 oraz art. 115 $\S 2$ k.k., Kraków 1998.

${ }^{68}$ K. Buchała, A. Zoll, Polskie prawo karne, Warszawa 1995, s. 224.

69 Ibidem.

70 Ibidem.

71 Por. zwłaszcza T. Kaczmarek, Materialna istota ..., s. 32 n. oraz omawianą tam literaturę. Autor konstatował: ,społeczne niebezpieczeństwo czynu stanowi treść materialną formalnego zespołu znamion przestępstwa, a więc jego merytoryczny zakres”. Dodawał jednakowoż: „Merytoryczny zakres ustawowych znamion nie zawsze będzie się pokrywał z jego formalnym zakresem", s. 42.

72 Stownik języka polskiego, red. M. Szewczyk, Warszawa 1978, s. 893. 
dokonywania ocen z punktu widzenia tego pozanormatywnego kryterium. W tym znaczeniu ocena społecznej szkodliwości powielałaby jednak jedynie ocenę dokonywaną przy preferowanym w nauce „wartościującym” typie bezprawności.

Słusznie A. Zoll powiada, że ,jeżeli element materialny może stanowić wystarczającą podstawę ukarania, bez potrzeby zrealizowania przez czyn określonych ustawą znamion typu czynu zabronionego, to można jednoznacznie powiedzieć, że prawo karne pozbawione jest swojej funkcji gwarancyjnej" ${ }^{\prime 3}$. W prawie karnym obowiązywać musi fundamentalna zasada nullum crimen sine lege. Zoll zastanawiał się, czy umieszczenie w ustawie obok tej zasady dyrektywy nullum crimen sine periculo sociali jest celowe. To przecież przede wszystkim dyrektywa zwrócona wobec prawodawcy, stąd postulat podniesienia jej do rangi konstytucyjnej. Sędzia nie ma prawa kwestionować oceny prawodawcy i uznać, że na przykład bigamia nie zasługuje na karę. Zasada ta jest związana ściśle z konstytucyjnym podziałem władz. Zoll ujmuje rzecz kategorycznie: „patrząc z tego punktu widzenia, umieszczenie zasady nullum crimen sine periculo sociali $\mathrm{w}$ kodeksie karnym jest wręc z błędne [wyr. - W.Z.]. Takie umieszczenie ma znaczenie czysto ideologiczne, co naturalnie nie może być akceptowane w przyszłym kodeksie karnym"74. Ostatecznie społeczna szkodliwość pojawia się jednak w kodeksie jako „korektura opisu ustawowego”, „klauzula generalna”. Zoll wyraźnie waha się co do słuszności podjętej decyzji projektu. Dla niego zasada nullum crimen sine periculo sociali ma przede wszystkim walor konstytucyjny ${ }^{75}$. Korektura karania zachowań bagatelnych mogła być rozwiązana na dwa sposoby: „poprzez akceptowanie zasady oportunizmu albo na drodze materialnoprawnej przez wprowadzenie na drodze materialnoprawnej do struktury przestępstwa dodatkowego elementu. Projekt wybrał to drugie rozwiązanie"76.

Efektem przyjętego stanowiska było wyeliminowanie społecznej szkodliwości z $§ 1$ art. 1 k.k. określającego istotę przestępstwa i ostateczne wpisanie jej do art. $1 \S 2$ k.k. Obie omawiane zasady nie są równe. Pierwszeństwo ma formalizm ${ }^{77}$.

W nauce, już na gruncie k.k. z 1997 roku, przeprowadzono gruntowną krytykę fundamentalnej dla istnienia pojęcia społecznej szkodliwości w prawie karnym, tezy mówiącej, że społeczna szkodliwość to kryterium zewnętrzne, rozumiane jako „byt obiektywny” wobec ustawy. Ewa Plebanek wskazuje, że

73 A. Zoll, Materialne określenie przestępstwa w projekcie..., s. 84.

74 Ibidem, s. 85.

75 Ibidem, s. 88.

76 Ibidem.

77 Por. krytykę obecnego ujęcia ustawowego T. Kaczmarek, Materialna treść przestępstwa jako problem kodyfikacyjny, [w:] Rozważania o prawie karnym. Ksiega pamiatkowa ku czci Prof. dra Aleksandra Ratajczaka, red. A. Szwarc, Poznań 1999, s. 171 n. O wspomnianej zasadzie autor pisał kategorycznie; „Przyjmując w przeciwieństwie do A. Zolla, że zasada nullum crimen sine periculo sociali ma zarówno swój wyraźny wymiar konstytucyjny, jak i prawnokarny, i że z tego względu jej adresatem jest tak ustawodawca, jak i sędzia, uważam, że jej pominięcie w art. $1 \S 1$ k.k. nie ma żadnego merytorycznego uzasadnienia", s. 182. 
pogląd o społecznej szkodliwości jako bycie obiektywnym należy odrzucić, gdyż założenie, że socjologia jest w stanie dostarczyć ustawodawcy obiektywnego „kryterium prawdy”, jest obarczone już u podstaw poważnym błędem metodologicznym. Uznanie materialnej treści przestępstwa (,społecznej szkodliwości”) za byt obiektywny pozostawiałoby ustawodawcy niczym nieograniczone pole podejmowania decyzji kryminalizacyjnych ${ }^{78}$.

Choć wydaje się, że wskazana teza jest postawiona nazbyt kategorycznie, warto ją odnotować. Założenie, że ustawodawca jest nieracjonalny, to pogląd, przynajmniej z punktu widzenia stosowania prawa w „państwie prawa”, ryzykowny. Nota bene prawodawca nie opiera się na danych czy metodologii wywiedzionej z jednej nauki ${ }^{79}$, niemniej jednak trafnie uchwycono trudności związane z oceną społecznej szkodliwości czynu. Skoro prawodawca ma mieć z tym problem, to cóż powiedzieć o organach stosujących prawo?

Przez cały okres obowiązywania art. 49 k.p.k. w wersji po 1949 roku, jak k.k. z 1969 roku, powracała kwestia wypracowania jednolitej praktyki opartej na dającym się zaakceptować wzorcu - precedensie ${ }^{80}$. Zapowiadano, że siła bezwładu wadliwej praktyki przeniesie się na praktykę stosowania prawa po rządem nowej ustawy z 1997 roku. Konstatacja finalna M. Rodzynkiewicza, że „funkcjonowanie instytucji prawa karnego nie realizuje w tym zakresie [stosowania instytucji społecznego niebezpieczeństwa — szkodliwości — W.Z.] postulatu sprawiedliwości formalnej" ${ }^{81}$, niestety się potwierdziła.

Aby zapobiec dowolności w tym zakresie, w kodeksie karnym z 1997 roku wpisano do $\S 2$ art. 115 k.k. funktory społecznej szkodliwości ${ }^{82}$. Spodziewano się, że określenie czytelnych mierników zapobiegnie dowolności ocen. Tymczasem w praktyce stało się inaczej. Przykładowo, w podsumowaniu badań przeprowadzonych na podstawie danych z 2005 roku czytamy:

Przeprowadzone badanie aktowe wskazało, że odsetek spraw zawierających uzasadnienie, w których decyzje o umorzeniu postępowania uwagi na brak karygodności czynu wydano częściowo lub całkowicie podstawie nieprawidłowych kryteriów, wyniósł 57\%. Oznacza to, że ponad połowa przebadanych orzeczeń była wadliwa w całości lub w części zapadła $\mathrm{z}$ na-

78 E. Plebanek, Materialne określenie przestęstwa, Warszawa 2009, s. 288 n.

79 Por przegląd stanowisk P. Kantor-Kozdrowicki, Racjonalność prawodawcy jako paradygmat nauk prawnych, „Folia Iuridica Universitatis Wratislaviensis” 7, 2018, nr 1, s. 95-110.

80 Po wnikliwej analizie orzecznictwa T. Kaczmarek konkludował: ,nauka prawa, jak dotąd, nie wypracowała dostatecznie zweryfikowanej koncepcji zobiektywizowanych wskaźników (kwantyfikatorów) określonego stopnia społecznego niebezpieczeństwa. [...] sąd zmuszony jest w rezultacie, w sposób intuicyjny ustalać na podstawie okoliczności czynu »wysoki«, »poważny«, »duży«, »znaczny«, »znikomy« czy »nieznaczny« stopień społecznego niebezpieczeństwa czynu”, idem, Ogólne dyrektywy wymiaru kary w teorii i praktyce sądowej, Wrocław 1980, s. 162-163.

81 M. Rodzynkiewicz, Modelowanie pojęć w prawie karnym, Kraków 1998, s. 76, oraz omówione tam wybrane wyniki badań empirycznych.

82 Przepis stanowi: Przy ocenie stopnia społecznej szkodliwości czynu sąd bierze pod uwagę rodzaj i charakter naruszonego dobra, rozmiary wyrządzonej lub grożącej szkody, sposób i okoliczności popełnienia czynu, wagę naruszonych przez sprawcę obowiązków, jak również postać zamiaru, motywację sprawcy, rodzaj naruszonych reguł ostrożności i stopień ich naruszenia. 
ruszeniem treści art. $1 \S 2$ k.k. Na podstawie wyłącznie prawidłowych kryteriów umorzono jedynie $35 \%$ spraw w postępowaniu przygotowawczym i $54 \% \mathrm{w}$ postępowaniu sądowym. $\mathrm{W}$ tej sytuacji ocena stosowania przez organy procesowe omawianej instytucji może być jedynie negatywna ${ }^{83}$.

Także ostatnio wskazuje się na różnice w sposobach dekodowania funktorów społecznej szkodliwości w orzecznictwie.

Wątpliwości wywołuje kwestia, jakie dokładnie funktory wpływają na ocenę stopnia nasilenia tej przesłanki. Wedle jednego stanowiska, ocenie podlega jedynie czyn sprawcy. Inne stanowisko przy ocenie społecznej szkodliwości bierze pod uwagę także okoliczności związane z osobą sprawcy, społecznym poczuciem sprawiedliwości czy też prewencją ogólną ${ }^{84}$.

Jak widać, ustawa nie przyniosła rozwiązania.

\section{Podsumowanie}

Wprowadzenie społecznej szkodliwości (społecznego niebezpieczeństwa) ${ }^{85}$ do polskiego prawa karnego było motywowane politycznie. Dla wielu już ta okoliczność jest wystarczająca do formułowania postulatów o konieczności usunięcia tej przesłanki odpowiedzialność karnej (Filar, Mącior, Kochanowski).

Funkcjonowanie społecznej szkodliwości przyczynia się do błędów i rozchwiań orzecznictwa, nawet w sprawach o zbrodnie. W orzecznictwie przeważa linia, sprzeczna z postulatami między innymi Władysława Woltera ${ }^{86}$, zakładająca, że zbrodnia może być uznana za czyn społecznie znikomo szkodliwy ${ }^{87}$, co $\mathrm{w}$ samo w sobie jest kuriozum, lecz niestety mające podstawy w ustawie.

83 K. Mielcarek, Znikoma społeczna szkodliwość czynu w praktyce prokuratorskiej i sądowej, „Prawo w Działaniu” 2008, nr 5, s. 237. Autor wskazuje, że „zbadano ogółem 402 sprawy karne prawomocnie zakończone umorzeniem postępowania na podstawie art. $17 \S 1$ pkt 3 k.p.k. w 2005 r. Materiał ten obejmował 179 spraw zakończonych na etapie postępowania przygotowawczego w prokuraturach rejonowych i 223 sprawy zakończone orzeczeniem sądu rejonowego", s. 204.

${ }^{84}$ Por. W. Kowalski, Okoliczności wptywające na ocenę stopnia społecznej szkodliwości czynu w kontekście warunkowego umorzenia postępowania karnego, LEX 2018; analiza orzecznictwa: R. Signerski, Warunkowe umorzenie postępowania karnego - okoliczności wptywające na ocenę stopnia społecznej szkodliwości czynu, LEX 2018.

85 W. Mącior zauważył, że w obu kolejnych projektach k.k. z 1990 r. tej samej treści nadawano różne nazwy: „uderzające jest, że w omawianej tu wersji projektu pojęcie »społecznej szkodliwości czynu« wyjaśniono (art. 113 § 3) tak samo jak pojęcie »społecznego niebezpieczeństwa czynu« w marcowej wersji projektu (art. 115 § 3). Nie da się więc zaprzeczyć, że problem określenia materialnej strony przestępstwa rozwiązano w gruncie rzeczy przez zastąpienie jednej nazwy drugą nazwą", idem, W sprawie reformy..., s. 90.

${ }^{86}$ W. Wolter, Nauka o przestępstwie..., s. $256 \mathrm{n}$.

87 Por. przegląd orzeczeń K. Janczukowicz, Znikomość społecznej szkodliwości zbrodni, LEX 2015. 
Jeśli przyjmuje się wartościujące ujęcie bezprawności, winno się zrezygnować, jak się wydaje, z karygodności jako przesłanki odpowiedzialności i na odwrót. Inaczej powiela się jedynie ocenę celowościową, nie wprowadzając nowych elementów do rozważań o przestępstwie. Prowadzi to do niepewności obrotu i narusza funkcję gwarancyjną prawa stanowionego ${ }^{88}$.

Ograniczenie liczby spraw drobnych z punktu widzenia państwowego prawa do karania, paraliżujących swą liczbą wymiar sprawiedliwości, winno się odbywać na innej drodze niż wprowadzenie społecznej szkodliwości czynu jako kryterium przesądzającego o karygodności. Przyjęte rozwiązanie podważa sens zasady formalizmu. Oczywiście rozwiązanie to nie oznacza, że zasada nullum crimen sine periculo sociali zastępuje zasadę nullum crimen sine lege i wyłącza gwarancje płynące $\mathrm{z}$ formalizmu. Wydaje się jednak rozwiązaniem nieracjonalnym i niefunkcjonalnym z punktu widzenia zasady pewności prawa. Znamienne, że zwolennicy zachowania materialnej definicji w kodeksie karnym z 1997 roku w kluczowej fazie sporów ograniczali się niekiedy do argumentów w rodzaju konieczności zachowania względu na humanizm w karaniu, ultima ratio prawa karnego czy temu, że ,czynnik materialny [...] służy wyraźnie teoretycznemu uzasadnieniu funkcjonowania kontratypów, szczególnie pozaustawowych" 89 . Ten ostatni argument jawi się jako szczególnie osobliwy, albowiem twórcy k.k. z 1997 roku programowo niemal odrzucają istnienie kontratypów pozaustawowych ${ }^{90}$. Na dwa zaś pierwsze argumenty można odpowiedzieć, wskazując, że analogiczny efekt osiąga się odpowiednim ukształtowaniem w prawie procesowym zasady de minimis non curat praetor.

Właściwszym posunięciem wydaje się ocena celowości ścigania czynu, a więc przez wprowadzenie i realizację zasady oportunizmu w postępowaniu karnym, choćby na wzór art. 49 k.k. w brzmieniu pierwotnym z 1949 roku, tu przytoczonym. Za zwiększaniem oportunizmu i kontradyktoryjności opowiadają się również ci polscy sędziowie, którzy zechcieli się wypowiedzieć w zakresie komparatystyki systemów prawa ${ }^{91}$. Największym uznaniem cieszą się model anglosaski i niemiecki.

Strony winny mieć także możliwość ugodowego załatwienia swoich spraw poza sądem, w ramach alternatywnych sposobów rozwiązania sporu.

Projektodawcy k.k. z 1997 roku uznali za stosowne umotywować zmianę nomenklatury „społeczne niebezpieczeństwo” na „społeczną szkodliwość” w ustawie,

88 Por. co do Bewertungsnorm: W. Wróbel, Relacyjne i wartościujace ujęcie bezprawności w prawie karnym, „Przegląd Prawa Karnego” 1993, z. 8, s. 13, 14.

89 Por. T. Bojarski, Społeczna szkodliwość i wina w projekcie k.k., [w:] Problemy kodyfikacji prawa karnego..., s. 73.

90 Por. zwłaszcza A. Zoll, „Pozaustawowe” okoliczności wyłączające odpowiedzialność karna w świetle konstytucyjnej zasady podziału władz, [w:] W kręgu teorii i praktyki prawa karnego. Księga poświęcona pamięci prof. Andrzeja Wąska, Lublin 2005, s. 425-438.

${ }_{91}$ Por. J. Królikowska, Sędziowie o karze, karaniu i bezkarności. Socjologiczna analiza sędziowskiego wymiaru kary, Warszawa 2020, s. 160 n. 
między innymi ze względu na konieczność dezaktualizacji „tych kierunków w orzecznictwie, które łączyły karygodność czynu z dotychczasowym życiem sprawcy, jego opinią, karalnością, nagminnością, a więc okolicznościami, które nie mają związku ani z przedmiotową, ani z podmiotową stroną czynu zabronionego" ${ }^{92}$. Drugi motyw zmiany nomenklatury, a więc jak twierdzą projektodawcy, że pojęcie społeczne niebezpieczeństwo czynu jest obciążone przypisywanymi mu treściami natury ideologicznej i politycznej, jest wątpliwy. Istota sprawy nie sprowadza się bowiem do tego, jak w państwie totalnym określano materialną treść, lecz czemu ona służyła. Określeń materialnej treści było bowiem wiele, i w nauce, i w prawie, posługiwano się pojęciem „społeczna szkodliwość” wymiennie ze ,społeczne niebezpieczeństwo". Tworzono nawet oryginalne, indywidualne propozycje w rodzaju obiektywnej antyspołeczności czynu - M. Cieślaka - jako odpowiednika społecznej szkodliwości ${ }^{93}$. Nie jest bynajmniej tak, jak twierdził Leon Tyszkiewicz, iżby wyzbycie się skojarzeń z socjalistyczną nauką i praktyką prawa karnego nie było trudne ${ }^{94}$. Aby starczała, jak twierdzili projektodawcy, zmiana terminu. Zawsze pozostanie jasne, że u podstaw instytucji legł pogląd, iż „przestępstwem mogą być jedynie czyny społecznie niebezpieczne, tj. stanowiące zamach na państwo socjalistyczne i ustanowiony w nim porządek prawny”, że „ta klasowa definicja przestępstwa, będąca kamieniem węgielnym prawa socjalistycznego, decyduje w sposób zasadniczy o zupełnie nowym, jakościowo odmiennym jego charakterze, określa wszystkie jego instytucje" 95 .

Prawo karne postrzegane było jako narzędzie. Obecnie ma stanowić ultima ratio. Jest jasne, że przesądzenie istoty przestępstwa i jego charakteru, wprowadzenie do ustawy „tego, co należy do literatury” było konieczne w prawie państwa totalnego, narzucającym swe poglądy i moralność społeczeństwu. W prawie państwa demokratycznego, państwie prawa, ustawowa deklaracja ideologiczna dotycząca istoty przestępstwa wydaje się zbędna. Narzuca pogląd o konfliktowym rozumieniu prawa karnego ${ }^{96}$. Zmiana nomenklatury tu jednak nie wystarcza.

$\mathrm{Na}$ koniec cytat z Igora Andrejewa, zamykający jego rozważania o materialnej definicji przestępstwa w Polsce, a stanowiący swoiste przesłanie: ,Jest w tych uwagach mniej zapału, entuzjazmu do instytucji, niż go miano niegdyś, bo dziś krytycyzm własnej doktryny u praktyki jest lepiej odczuwalnym, nieodzownym warunkiem myślenia naukowego"97.

92 Nowe kodeksy karne z 1997 r. z uzasadnieniami, Warszawa 1997, s. 118.

93 Por. M. Cieślak, Polskie prawo..., s. 254.

94 Por. L. Tyszkiewicz, O definicji przestępstwa jej strukturze i elementach, „Problemy Prawa Karnego" 21, 1995, s. 47.

95 G. Auscaler, op. cit., s. 151.

96 Por. J. Kochanowski, op. cit., s. 15.

97 I. Andrejew, op. cit., s. 105. 


\section{Bibliografia}

Administratywizacja prawa karnego, czy kryminalizacja prawa administracyjnego?, red. M. Bogusz, W. Zalewski, Gdańsk 2021 (w druku).

Ambos K., National Socialist Criminal Law. Continuity and Radicalization, Baden-Baden 2019.

Andrejew I., Podstawowe pojęcia nauki o przestępstwie, Warszawa 1988.

Andrejew I., Lernell L., Sawicki J., Prawo karne Polski Ludowej. Wiadomości ogólne, Warszawa 1954.

Andrejew I., Sawicki J., Istota przestępstwa w Polsce Ludowej, Warszawa 1951.

Andrejew I., Sawicki J., Istota przestępstwa w Polsce Ludowej. Kilka uwag z zakresu teorii prawa karnego, Warszawa 1949.

Auscaler G., Stan wyższej konieczności w prawie karnym, Warszawa 1953.

Bałandynowicz A., Probacyjna sprawiedliwość karząca, Warszawa 2015.

Bohlander M., Vormbaum T., A Modern History of German Criminal Law, Berlin-Heidelberg 2014.

Bojarski T., Spoleczna szkodliwość i wina w projekcie k.k., [w:] Problemy kodyfikacji prawa karnego. Księga ku czci Profesora Mariana Cieślaka, Kraków 1993.

Bojarski T., W sprawie funkcji art. 26 k.k., „Palestra” 1971, nr 4.

Bosiacki A., Uźródet ,,socjalizmu realnego”: koncepcja prawa wedtug Lenina, „Studia Iuridica” 35, 1998.

Buchała K., Zoll A., Kodeks karny. Częsśc ogólna. Komentarz do art. 1 oraz art. 115 § 2 k.k., Kraków 1998.

Buchała K., Zoll A., Polskie prawo karne, Warszawa 1995.

Cieślak M., Polskie prawo karne, Warszawa 1995.

Cieślak M., Proces karny, cz. 2, Kraków 1953.

Daszkiewicz K., Kodeks karny z 1997 roku. Uwagi krytyczne, Gdańsk 2001.

Dobinson I., The Criminal Law of the People's Republic of China (1997): Real change or rhetoric?, „Washington International Law Journal” 11, 2002, nr 1.

Dudek A., Reglamentowana rewolucja, Warszawa 2014.

Ferrajoli L., Zolo D., Marxism and the criminal question, „Law and Philosophy” 4, 1985, nr 1.

Filar M., O niektórych ogólnych zasadach odpowiedzialności karnej w projekcie Kodeksu karnego z sierpnia $1990 r$ - - polemicznie, „Państwo i Prawo” 1991, nr 4.

Filar M., O niektórych ogólnych zasadach odpowiedzialności karnej w projekcie Kodeksu karnego z sierpnia 1990 r. - polemicznie, [w:] Problemy reformy prawa karnego, red. T. Bojarski, E. Skrętowicz, Lublin 1993.

Filar M., W stużbie utopii. 73 lata radzieckiego prawa karnego, Torun 1992.

Fitting Ch., Analogieverbot und Kontinuität. Entwicklungslinien des strafrechtlichen Analogieverbots seit 1871, Berlin 2016.

Gałązka M., Społeczne niebezpieczeństwo czynu w komunistycznym prawie karnym Polski Ludowej, [w:] Komunistyczne prawo karne Polski Ludowej, red. A. Grześkowiak, Lublin 2007.

Górniok O., Czyny o niktym niebezpieczeństwie społecznym, „Nowe Prawo” 1963, nr 7-8.

Jakubowski G., Sądownictwo powszechne w Polsce w latach 1944-1950, Warszawa 2002.

Janczukowicz K., Znikomość społecznej szkodliwości zbrodni, LEX 2015.

Kaczmarek T., Materialna istota przestęstwa i jego ustawowe znamiona, Wrocław 1968.

Kaczmarek T., Materialna treść przestępstwa jako problem kodyfikacyjny, [w:] Rozważania o prawie karnym, Księga pamiatkowa ku czci Prof. dra Aleksandra Ratajczaka, red. A. Szwarc, Poznań 1999.

Kaczmarek T., Ogólne dyrektywy wymiaru kary w teorii i praktyce sadowej, Wrocław 1980.

Kantor-Kozdrowicki P., Racjonalność prawodawcy jako paradygmat nauk prawnych, „,Folia Iuridica Universitatis Wratislaviensis" 7, 2018, nr 1. 
Kita J., Pytlas S., Profesorowie Uniwersytetu Łódzkiego 1945-1994. Pro Memoria, Łódź 1995.

Kochanowski J., Przeciwko pośpiesznej kodyfikacji karnej, „Palestra” 1990, nr 8-9.

Komunistyczne prawo karne Polski Ludowej, red. A. Grześkowiak, Lublin 2007.

Kowalski W., Okoliczności wpływające na ocenę stopnia społecznej szkodliwości czynu w kontekście warunkowego umorzenia postępowania karnego, LEX 2018.

Krajewski K., Spór o politykę karna w Polsce: problem kary pozbawienia wolności z warunkowym zawieszeniem jej wykonania i alternatyw pozbawienia wolności, „Przegląd Więziennictwa Polskiego" 2007, nr 54.

Królikowska J., Sędziowie o karze, karaniu i bezkarności. Socjologiczna analiza sędziowskiego wymiaru kary, Warszawa 2020.

Krukowski A., Materialna treść przestępstwa a okoliczności wytączające odpowiedzialność karna, „Nowe Prawo” 1971, nr 12.

Lityński A., Historia prawa karnego Polski Ludowej, Warszawa 2005.

Makarewicz J., Slowo wstęne, [w:] Kodeks karny republik sowieckich, Warszawa 1927.

Makowski W., Uwagi w sprawie koniecznych zmian i uzupetnień części ogólnej projektu kodeksu karnego, RPEiS 3, 1929.

Marek A., Stopień społecznego niebezpieczeństwa czynu jako podstawa umorzenia postępowania karnego, Toruń 1970.

Mącior W., Negatywny wpływ marksizmu na polska naukę prawa karnego, „Palestra” 1990, nr 8-9.

Mącior W., W sprawie reformy prawa karnego, „Państwo i Prawo” 1991, z. 10.

Melezini M., Punitywność polskiego wymiaru sprawiedliwości w XX wieku, Białystok 2003.

Melezini M., Środki karne jako instrument polityki kryminalnej, Białystok 2013.

Mielcarek K., Znikoma społeczna szkodliwość czynu w praktyce prokuratorskiej i sądowej, „Prawo w Działaniu" 2008, nr 5.

Nowe kodeksy karne z 1997 r. z uzasadnieniami, Warszawa 1997.

Olszewski M., Czy utrzymać pojęcie społecznego niebezpieczeństwa czynu w prawie karnym, „Państwo i Prawo" 1958, nr 3.

Plebanek E., Materialne określenie przestępstwa, Warszawa 2009.

Prawo karne w okresie stalinizmu, red. G. Rejman, („Studia Iuridica” 27), Warszawa 1995.

Projekt kodeksu karnego Polski Ludowej. Część ogólna, Warszawa 1951.

Rajzman H., Sprawa wyktadni, wytycznych czy ustawy, „Państwo i Prawo” 1958, nr 8-9.

Reinhold J., Pojęcie i zakres polityki kryminalnej, „Czasopismo Prawne i Ekonomiczne” 19, 1921.

Rodzynkiewicz M., Modelowanie pojęć w prawie karnym, Kraków 1998.

Romanowska E., Prokurator z pasja, „W Sieci historii” 2020, nr 7-8.

Ryszka F., Państwo stanu wyjątkowego. Rzecz o systemie państwa i prawa III Rzeszy, Wrocław 1985.

Siewierski M., Przegląd orzecznictwa SN, „Państwo i Prawo” 1964, nr 12.

Signerski R., Warunkowe umorzenie postẹpowania karnego - okoliczności wptywające na ocenę stopnia społecznej szkodliwości czynu, LEX 2018.

Smoleński J., Problematyka materialnej istoty przestępstwa w projekcie k.k., „Państwo i Prawo” 1963, nr 8-9.

Solomon P.H., Soviet Criminal Justice under Stalin, Cambridge 1996.

Szerer M., Karanie a humanizm, Warszawa 1964.

Tokarczyk R., Wspótczesne doktryny polityczne, Lublin 1984.

Tyszkiewicz L., O definicji przestepstwa jej strukturze i elementach, „Problemy Prawa Karnego" 21, 1995.

Wąsek A., Wprowadzenie do belgijskiego prawa karnego, Warszawa 1995.

Wąsowicz M., Nurt socjologiczny w polskiej myśli prawnokarnej, Warszawa 1989.

Wolter W., Nauka o przestępstwie, Warszawa 1973.

Wolter W., Prawo karne, Warszawa 1947. 
Wróbel W., Relacyjne i wartościujące ujęcie bezprawności w prawie karnym, „Przegląd Prawa Karnego" 1993, z. 8.

Zaborski M., [rec.] „Prawo karne w okresie stalinizmu”, pod red. nauk. Genowefy Rejman, Warszawa 1995, „Palestra” 40, 1996, nr 3-4.

Zajadło J., Dziedzictwo przeszłości. Gustaw Radbruch: portret filozofa, prawnika, polityka i humanisty, Gdańsk 2007.

Zajadło J., Formuła Radbrucha, Gdańsk 2001.

Zalewski W., Komentarz do art. 3 k.k., [w:] Kodeks karny. Komentarz, red. M. Królikowski, R. Zawłocki, t. 1, Warszawa 2017.

Zalewski W., Sprawiedliwość naprawcza. Początek ewolucji polskiego prawa karnego?, Gdańsk 2006.

Zawłocki R., Pojęcie i funkcje społecznej szkodliwości czynu w prawie karnym, Warszawa 2007.

Ziemba Z.A., Prawo przeciwko społeczeństwu, Warszawa 1997.

Zoll A., Materialne określenie przestępstwa, „Prokuratura i Prawo” 1997, nr 2.

Zoll A., Materialne określenie przestępstwa w projekcie kodeksu karnego, [w:] Problemy kodyfikacji prawa karnego. Księga ku czci Profesora Mariana Cieślaka, Kraków 1993.

Zoll A., O reformie prawa karnego (w odpowiedzi W. Maciorowi), „Państwo i Prawo” 1992, nr 1.

Zoll A., Ogólne zasady odpowiedzialności karnej w projekcie kodeksu karnego, „Państwo i Prawo” 1990, nr 10.

Zoll A., „Pozaustawowe” okoliczności wyłączające odpowiedzialność karna w świetle konstytucyjnej zasady podziału władz, [w:] W kręgu teorii i praktyki prawa karnego. Księga poświęcona pamięci prof. Andrzeja Waska, Lublin 2005.

Zoll A., Spójrzmy inaczej, „Wokanda”1990, nr 28.

Zoll A., Zasady odpowiedzialności karnej, „Nowa Kodyfikacja Karna. Kodeks karny” 1998, z. 12. 